\title{
Review
}

Pharmacology

Pharmacology 2014;94:60-70

DOI: $10.1159 / 000366164$
Received: June 20, 2014

Accepted after revision: July 27, 2014 Published online: September 2, 2014

\section{Montelukast-Induced Adverse Drug Reactions: A Review of Case Reports in the Literature}

\author{
Gioacchino Calapai $^{\mathrm{b}}$ Marco Casciaro $^{\mathrm{a}}$ Marco Miroddi $^{\mathrm{b}}$ Fabrizio Calapai $^{\mathrm{b}}$ \\ Michele Navarra ${ }^{c}$ Sebastiano Gangemi ${ }^{a}{ }^{a}$ \\ ${ }^{a}$ School and Division of Allergology and Clinical Immunology, at ${ }^{b}$ Department of Clinical and Experimental \\ Medicine, and ${ }^{\mathrm{C}}$ Department of Drug Sciences and Health Products, University of Messina, and ${ }^{\mathrm{d}}$ Institute of Clinical \\ Physiology (IFC), Consiglio Nazionale delle Ricerche (CNR), Messina Unit, Messina, Italy
}

\section{Key Words}

Montelukast · Adverse drug reaction - Anti-leucotrienes . Allergy · Asthma · Hypersensitivity · Pharmacovigilance · Churg-Strauss syndrome $\cdot$ Toxicity

\begin{abstract}
Background: Montelukast, a leucotriene receptor antagonist, binds the cysteinyl leucotriene type 1 receptor. Montelukast is commonly prescribed to asthma patients as add-on therapy to inhaled corticosteroids. Several clinical trials emphasized that montelukast can be considered a safe drug. However, recent evidence reconsidered the benefit/risk ratio of the use of montelukast for both paediatric and adult patients. Summary: The present review analyzed the previous published case reports regarding montelukast-induced adverse drug reactions (ADRs). They included agitation, anxiety, depression, sleep disturbance, hallucinations, suicidal thinking and suicidality, tremor, dizziness, drowsiness, neuropathies and seizures. The immune system can be involved, in particular, cases of Churg-Strauss syndrome have been published. Furthermore, it can induce hypersensitivity reactions, including anaphylaxis and eosinophilic infiltration. In
\end{abstract}

addition, hepatobiliary, pancreatic and uropoietic disorders have been observed. Some of these cases are characterized by severe prognosis (i.e. neurological deficit and fatal hepatotoxicity). Key Message: The use of montelukast can be burdened by several ADRs, of which physicians should be aware in their clinical practice. A better understanding of the mechanisms causing ADRs after using montelukast could help researchers and clinicians in defining a risk-reduction strategy aimed to lessen montelukast toxicity. More accurate epidemiological studies, in order to discover risk factors favouring montelukast-associated ADRs, are demanded.

(c) 2014 S. Karger AG, Basel

\section{Introduction}

Montelukast sodium is a selective leucotriene receptor antagonist (LTRA) that specifically blocks the cysteinyl leucotriene type 1 (CysLT1) receptor. CysLTs (LTC 4, LTD 4 and LTE 4) are important pro-asthmatic lipid mediators binding to CysLT receptors. The CysLT1 receptor is localized in the human airways and synthesized by a variety of cells, including mast cells, eosinophils, baso-

\section{KARGER}

E-Mail karger@karger.com

www.karger.com/pha
C 2014 S. Karger AG, Base

0031-7012/14/0942-0060\$39.50/0
Dr. Marco Miroddi, MD

Department of Clinical and Experimental Medicine Policlinico 'G. Martino', University of Messina Via Consolare Valeria 5, IT-98125 Messina (Italy)

E-Mail marcomiroddi@hotmail.com 
phils and macrophages [1]. CysLTs have been correlated with the pathophysiology of asthma and allergic rhinitis [2]. Montelukast is an orally active compound with antiinflammatory properties, which is effective in improving clinical parameters of asthmatic inflammation (i.e. respiratory function and FEV1 in clinical trials). It causes bronchodilation in addition to that produced by beta2-stimulating drugs [3].

Asthma is a chronic immunological disorder of the lung characterized by reversible airway obstruction, airway inflammation and increased airway hyperresponsiveness to provocative challenge [4]. As many as 300 million individuals of all ages, and all ethnic backgrounds, suffer from asthma, and the burden of this disease to public health is increasing worldwide [5]. LTRAs provide an alternative treatment for asthma patients who are not controlled by, not satisfied with or refuse to take inhaled corticosteroids (ICS) therapy $[6,7]$. In patients whose asthma is not controlled by ICS therapy, the addition of a second drug, rather than increasing the dose of ICS, can result in an improved control of the symptoms $[8,9]$.

\section{Background}

Montelukast is generally considered a safe drug with the occurrence of a few adverse drug reactions (ADRs). The overall incidence of adverse events (AEs) due to montelukast, based on clinical data, suggests that it is comparable to placebo and its use as add-on therapy does not seem to increase AEs in comparison to mono-therapy based on ICS or beta-2 stimulants [7, 10]. A review of clinical trials summarized the safety and tolerability information for montelukast evaluating data from 2,751 paediatric patients. The authors found that montelukast was well-tolerated, and the most frequent clinical AEs noticed in all treatments (placebo, montelukast and active control/usual care) in virtually all studies were upper respiratory infection, worsening asthma, pharyngitis and fever $[11,12]$.

A recent study has reconsidered the benefit/risk ratio in paediatric patients, suggesting that there is not sufficient proof to support therapeutic and safety advantages of anti-leucotriene use as add-on therapy in asthmatic children [13]. A Cochrane review, comparing long-acting beta- 2 agonists versus anti-leucotrienes (including montelukast) in children and adults on regular treatment with ICS, stated that anti-leucotrienes caused less incidences of serious AEs compared to long-acting beta-2 agonists

Review of Case Reports on

Montelukast-Induced Adverse Reactions
[14]. Although anti-leucotrienes are generally well-tolerated, several case reports describing ADRs after the use of montelukast have been published. For this reason, it appears desirable to explore and summarize the literature to offer a helpful perspective to clinicians, which enables them to better recognize and manage montelukast-induced ADRs.

\section{Methods}

A search of the scientific literature for case reports on montelukast and ADRs published prior to March 1, 2014, has been conducted. Two investigators independently collected articles from EMBASE, PubMed, Scopus, SciFinder, Web of Science and Google Scholar. The following keywords were used (alone or in combination): montelukast sodium, montelukast, antileukotriene, antileukotriene, leukotriene receptor antagonist, adverse reaction, adverse event, side effect, safety profile and toxicity. Only case reports where montelukast has been administered according to the dose indicated in the summary product characteristics (SPC) and articles in English were included. In this review, the case reports are summarized according to the systems or organs involved in the ADRs. Tables 1 and 2 give a brief overview of the main features of the case reports. We only included case reports where the full text of the article was available.

\section{Immune System Disorders}

Hypersensitivity Reactions Including Anaphylaxis,

Hepatic Eosinophilic Infiltration and Autoimmune

Vasculitis

Churg-Strauss syndrome (CSS) is a rare form of eosinophilic vasculitis associated with asthma $[15,16]$. Its incidence rate is approximately $1-2$ cases per million persons per year; it may range from 0.3 to 4 cases per million persons per year [17]. The possible role of LTRA therapy in the pathogenesis of CSS is still uncertain. Several case reports and case series describe the onset of CSS in patients receiving montelukast for the management of difficult-to-control moderate-to-severe asthma.

In their article, Bibby et al. [18] examined the association between LTRA therapy and CSS in cases detected in the Food Drug Administration (FDA) Adverse Event Reporting System database. The authors concluded that LTRA therapy was a suspected cause of CSS confirmed in 114 cases. In about two-thirds, it was not possible to associate pre-existing or possible prodromal CSS to the reduction in oral or ICS therapy [18].

In individuals suffering from asthma, LTRA-induced CSS commonly presents with a wide range of clinical 
Table 1. Summary of the case reports on montelukast-induced CSS

\begin{tabular}{|c|c|c|c|c|c|c|}
\hline Reference & Indication & $\begin{array}{l}\text { Age, years } \\
\text { Gender }\end{array}$ & $\begin{array}{l}\text { Dosage of } \\
\text { montelukast } \\
\text { Duration of } \\
\text { therapy }\end{array}$ & $\begin{array}{l}\text { Concomitant } \\
\text { therapy/-ies }\end{array}$ & ADRs & $\begin{array}{l}\text { Severity of ADRs } \\
\text { and prognosis }\end{array}$ \\
\hline $\begin{array}{l}\text { Anar et al., } \\
2012[30]\end{array}$ & $\begin{array}{l}\text { rhinitis, } \\
\text { asthma }\end{array}$ & 59, female & $\begin{array}{l}10 \mathrm{mg} \\
3 \text { years }\end{array}$ & $\begin{array}{l}\text { inhaled salmeterol, } \\
\text { beclomethasone }\end{array}$ & $\begin{array}{l}\text { CSS, bilateral pulmonary infiltrates, } \\
\text { leucocytosis, eosinophilia }\end{array}$ & $\begin{array}{l}\text { resolution within } \\
2 \text { months }\end{array}$ \\
\hline $\begin{array}{l}\text { Black et al., } \\
2009[34]\end{array}$ & $\begin{array}{l}\text { cough } \\
\text { asthma }\end{array}$ & 37, female & $\mathrm{NR}, \mathrm{NR}$ & $\begin{array}{l}\text { ICS, albuterol, } \\
\text { antibiotics }\end{array}$ & $\begin{array}{l}\text { CSS, pulmonary infiltrates, leucocytosis, } \\
\text { eosinophilia, nasal polyps }\end{array}$ & $\begin{array}{l}\text { resolution within } \\
1 \text { year }\end{array}$ \\
\hline \multirow[t]{3}{*}{$\begin{array}{l}\text { Cuchacovich } \\
\text { et al., } 2007 \\
{[23]}\end{array}$} & $\begin{array}{l}\text { asthma, } \\
\text { allergic } \\
\text { rhinitis }\end{array}$ & 68 , female & $\begin{array}{l}10 \text { mg once a } \\
\text { day, } \\
4 \text { months }\end{array}$ & $\begin{array}{l}\text { insulin, zocor } \\
\text { otensin, Lasix, } \\
\text { flonase, neurontin, } \\
\text { albuterol }\end{array}$ & $\begin{array}{l}\text { CSS, skin rash, dry cough, shortness of } \\
\text { breath, chest tightness }\end{array}$ & resolution \\
\hline & asthma & 43 , female & $\begin{array}{l}10 \mathrm{mg} \text { once } \\
\text { a day, } 1 \text { year }\end{array}$ & prednisone & $\begin{array}{l}\text { CSS, fever, generalized malaise, } \\
\text { arthralgias, jaundice with a serum } \\
\text { bilirubin at } 3 \mathrm{mg} / \mathrm{dl} \text {; liver } \\
\text { biopsy revealed eosinophilic hepatitis }\end{array}$ & resolution \\
\hline & asthma & 58 , female & $\begin{array}{l}10 \text { mg once a } \\
\text { day, } \\
6 \text { months }\end{array}$ & $\begin{array}{l}\text { prednisone up to } \\
40 \mathrm{mg} / \text { day, } \\
\text { albuterol }\end{array}$ & $\begin{array}{l}\text { CSS, fever, purpuric rash was present } \\
\text { on her lower extremities; synovitis of } \\
\text { the wrists; bilateral scleritis }\end{array}$ & resolution \\
\hline $\begin{array}{l}\text { Conen et al., } \\
2004[35]\end{array}$ & asthma & 46 , male & $\begin{array}{l}10 \mathrm{mg} \\
2 \mathrm{months}\end{array}$ & $\begin{array}{l}\text { ICS and } \\
\text { intermittent } \\
\text { salbutamol, oral } \\
\text { prednisone }\end{array}$ & $\begin{array}{l}\text { CSS, hepatojugular reflux and } \\
\text { inspiratory crackles, depressed left } \\
\text { ventricular function, pericardial } \\
\text { effusion, pulmonary infiltrates, } \\
\text { leucocytosis, eosinophilia }\end{array}$ & resolution \\
\hline $\begin{array}{l}\text { Currie et al., } \\
2008[24]\end{array}$ & asthma & 40 , male & $\begin{array}{l}10 \mathrm{mg} \\
1 \mathrm{month}\end{array}$ & $\begin{array}{l}250 \mathrm{mg} \text { fluticasone/ } \\
25 \mathrm{mg} \text { salmeterol } \\
\text { (2 puffs twice } \\
\text { daily) }\end{array}$ & $\begin{array}{l}\text { CSS, respiratory symptoms, } \\
\text { maculopapular rash, pulmonary } \\
\text { infiltrates, leucocytosis, eosinophilia }\end{array}$ & CSS abnormalities \\
\hline $\begin{array}{l}\text { Franco and Artés, } 1999 \\
\text { [31] }\end{array}$ & asthma & 26 , male & $\begin{array}{l}10 \mathrm{mg} \\
4 \mathrm{months}\end{array}$ & $\begin{array}{l}1,000 \mu \mathrm{g} \\
\text { fluticasone daily }\end{array}$ & pulmonary eosinophilia & resolution \\
\hline $\begin{array}{l}\text { Girszyn et al., } \\
2008 \text { [25] }\end{array}$ & asthma & 47, female & $\begin{array}{l}\text { NR, } \\
5 \text { months }\end{array}$ & NR & $\begin{array}{l}\text { CSS, fever, cutaneous manifestations, } \\
\text { pain and paraesthesias, pulmonary } \\
\text { infiltrates, leucocytosis, eosinophilia }\end{array}$ & resolution \\
\hline $\begin{array}{l}\text { Goransson and Omdal, } \\
2000[20]\end{array}$ & asthma & 46 , female & $\begin{array}{l}\text { NR, } \\
4 \text { months }\end{array}$ & $\begin{array}{l}\text { prednisolone, } \\
\text { budesonide, } \\
\text { formoterol, } \\
\text { terbutaline }\end{array}$ & $\begin{array}{l}\text { CSS, pulmonary infiltrates, leucocytosis, } \\
\text { eosinophilia, microscopic haematuria, } \\
\text { hyaline, granular and erythrocyte casts, } \\
1.6 \text { g urinary protein, necrotizing } \\
\text { glomerulonephritis }\end{array}$ & $\begin{array}{l}\text { resolution, } \\
\text { persistent } \\
\text { proteinuria }\end{array}$ \\
\hline $\begin{array}{l}\text { Jennings } \\
\text { et al., } 2009 \text { [26] }\end{array}$ & asthma & 21 , female & $\begin{array}{l}\mathrm{NR}, \\
5 \text { weeks }\end{array}$ & $\begin{array}{l}\text { fluticasone steroid } \\
\text { nebulizer, } \\
\text { salbutamol inhaler }\end{array}$ & $\begin{array}{l}\text { CSS, bronchiectasis, asthma and } \\
\text { eczema, bullous vasculitic rash, } \\
\text { pulmonary infiltrates, } \\
\text { leucocytosis, eosinophilia, ANCA }\end{array}$ & $\begin{array}{l}\text { resolution within } \\
4 \text { weeks }\end{array}$ \\
\hline $\begin{array}{l}\text { Matsui and } \\
\text { Nishijima, } 2011 \text { [29] }\end{array}$ & $\begin{array}{l}\text { asthma, } \\
\text { rhinitis }\end{array}$ & 64 , female & $\begin{array}{l}\text { NR, } \\
4 \text { months }\end{array}$ & atorvastatin & CCS with hepatitis & \\
\hline $\begin{array}{l}\text { Man et al., } \\
2012 \text { [27] }\end{array}$ & asthma & 62, female & $\begin{array}{l}10 \mathrm{mg} \\
5 \mathrm{months}\end{array}$ & $\begin{array}{l}50 / 500 \mu \mathrm{g} \\
\text { salmeterol/ } \\
\text { fluticasone }\end{array}$ & $\begin{array}{l}\text { CSS, pulmonary infiltrates, leucocytosis, } \\
\text { eosinophilia, fever, malaise, sensory } \\
\text { deficits in the lower extremities, diffuse } \\
\text { musculoskeletal and thoracic pain }\end{array}$ & resolution \\
\hline $\begin{array}{l}\text { Michael and } \\
\text { Murphy, } \\
2003 \text { [22] }\end{array}$ & asthma & 68 , male & $\begin{array}{l}\text { NR, } \\
3 \text { months }\end{array}$ & $\begin{array}{l}\text { beclomethasone, } \\
\text { ipratropium, } \\
\text { salbutamol } \\
\text { inhalers, aspirin, } \\
\text { nifedipine }\end{array}$ & $\begin{array}{l}\text { CSS, pulmonary infiltrates, leucocytosis, } \\
\text { eosinophilia, polyneuropathy }\end{array}$ & $\begin{array}{l}\text { partial resolution, } \\
\text { neurological deficit }\end{array}$ \\
\hline
\end{tabular}


Table 1. (continued)

\begin{tabular}{|c|c|c|c|c|c|c|c|}
\hline Reference & & Indication & $\begin{array}{l}\text { Age, years } \\
\text { Gender }\end{array}$ & $\begin{array}{l}\text { Dosage of } \\
\text { montelukast } \\
\text { Duration of } \\
\text { therapy }\end{array}$ & $\begin{array}{l}\text { Concomitant } \\
\text { therapy/-ies }\end{array}$ & ADRs & $\begin{array}{l}\text { Severity of ADRs } \\
\text { and prognosis }\end{array}$ \\
\hline $\begin{array}{l}\text { Mukhopadhyay } \\
\text { and Stanley, } \\
2001[38]\end{array}$ & & asthma & 56, male & $\begin{array}{l}10 \mathrm{mg} \\
6 \mathrm{months}\end{array}$ & $\begin{array}{l}1,000 \mu \mathrm{g} \\
\text { fluticasone, } 100 \mu \mathrm{g} \\
\text { salmeterol daily, } \\
\text { prednisolone }\end{array}$ & $\begin{array}{l}\text { CSS, proteinuria, rash, leucocytosis, } \\
\text { eosinophilia }\end{array}$ & $\begin{array}{l}\text { resolution of } \\
\text { symptoms only } \\
\text { with prednisolone } \\
10 \mathrm{mg} \\
\text { maintenance } \\
\text { therapy }\end{array}$ \\
\hline \multirow[t]{3}{*}{$\begin{array}{l}\text { Solans et al., } \\
2002[21]\end{array}$} & case 1 & CSS & 54 , male & $\begin{array}{l}10 \mathrm{mg} \\
2 \text { weeks }\end{array}$ & $\begin{array}{l}10 \mathrm{mg} / \text { day } \\
\text { prednisone, } \\
100 \mathrm{mg} / \text { day } \\
\text { cyclophosphamide }\end{array}$ & $\begin{array}{l}\text { relapse of CSS, fever, dyspnoea on } \\
\text { exertion, and polyarthralgia, rash, } \\
\text { rhonchi, wheezes, scattered coarse } \\
\text { crackles in the bases of both lungs, } \\
\text { pulmonary infiltrates, leucocytosis, } \\
\text { eosinophilia }\end{array}$ & $\begin{array}{l}\text { resolution on } 10 \\
\mathrm{mg} / \text { day prednisone } \\
\text { and } 100 \mathrm{mg} / \text { day } \\
\text { cyclophosphamide }\end{array}$ \\
\hline & case 2 & asthma & 60, female & $\begin{array}{l}10 \mathrm{mg} \\
4 \mathrm{months}\end{array}$ & $\begin{array}{l}\text { inhaled } \beta \text { agonists, } \\
\text { inhaled } \\
\text { steroids, oral } \\
\text { theophylline }\end{array}$ & $\begin{array}{l}\text { CSS, malaise, myalgia, polyarthralgia, } \\
\text { progressive numbness of and pain in } \\
\text { her lower and upper limbs, } \\
\text { erythematous exanthema, deep tendon } \\
\text { areflexia in the right upper limb and in } \\
\text { both lower limbs, with flexor plantar } \\
\text { responses, diminished sensation, } \\
\text { rheumatoid factor, ANCA, ANA, } \\
\text { leucocytosis, eosinophilia }\end{array}$ & $\begin{array}{l}\text { partial resolution, } \\
\text { sensorimotor } \\
\text { sequelae }\end{array}$ \\
\hline & case 3 & asthma & 62, female & $\begin{array}{l}10 \mathrm{mg} \text {, } \\
10 \text { days }\end{array}$ & $\begin{array}{l}\text { salmeterol and } \\
\text { fluticasone } \\
\text { propionate }\end{array}$ & $\begin{array}{l}\text { CSS, malaise, myalgia, swollen ankles, } \\
\text { polyarthralgia, and palpable purpura } \\
\text { over both legs, leucocytosis, } \\
\text { eosinophilia }\end{array}$ & resolution \\
\hline $\begin{array}{l}\text { Tuggey and } \\
\text { Hosker, } \\
2000[32]\end{array}$ & & asthma & 72, female & $\begin{array}{l}10 \mathrm{mg} \\
4 \text { weeks }\end{array}$ & $\begin{array}{l}750 \mu \mathrm{g} \text { fluticasone } \\
\text { twice daily together } \\
\text { with } 50 \mu \mathrm{g} \text { inhaled } \\
\text { salmeterol } \\
\text { twice daily }\end{array}$ & $\begin{array}{l}\text { CSS, cough and breathlessness, } \\
\text { swollen ankles, polyarthralgia, and } \\
\text { numbness, malaise, inspiratory crackles, } \\
\text { expiratory wheeze, rash, pulmonary } \\
\text { infiltrates, leucocytosis, eosinophilia }\end{array}$ & resolution \\
\hline $\begin{array}{l}\text { Uyar et al., } \\
2012 \text { [39] }\end{array}$ & & asthma & 18 , male & $\begin{array}{l}\text { NR, } \\
6 \text { months }\end{array}$ & $\begin{array}{l}\text { fluticasone } \\
\text { propionate and } \\
\text { salmeterol 500/ } \\
50 \mu \mathrm{g} \text { twice daily }\end{array}$ & $\begin{array}{l}\text { CSS, cough, dyspnoea and haemoptysis, } \\
\text { pulmonary infiltrates, leucocytosis, } \\
\text { eosinophilia }\end{array}$ & $\begin{array}{l}\text { significant } \\
\text { improvement }\end{array}$ \\
\hline $\begin{array}{l}\text { Villena } \\
\text { et al., } 2000 \\
{[19]}\end{array}$ & & asthma & 25 , female & $\begin{array}{l}10 \mathrm{mg} \\
5 \mathrm{months}\end{array}$ & $\begin{array}{l}\text { fluticasone, } \\
\text { formoterol, } \\
\text { terbutaline }\end{array}$ & $\begin{array}{l}\text { CSS, fever, rash, proteinuria, pulmonary } \\
\text { infiltrates, leucocytosis, eosinophilia }\end{array}$ & $\begin{array}{l}\text { resolution on } 15 \\
\text { mg/day prednisone }\end{array}$ \\
\hline \multirow[t]{4}{*}{$\begin{array}{l}\text { Wechsler } \\
\text { et al., } 2000 \\
{[28]}\end{array}$} & case 1 & asthma & 62, female & $\begin{array}{l}\text { NR, } \\
3 \text { months }\end{array}$ & ICS & $\begin{array}{l}\text { CSS, musculoskeletal pain, weakness, } \\
\text { sensory loss in both lower and upper } \\
\text { extremities, rash, leucocytosis, } \\
\text { eosinophilia }\end{array}$ & $\begin{array}{l}\text { partial resolution } \\
\text { of polyneuropathy }\end{array}$ \\
\hline & case 2 & asthma & 25 , male & $\begin{array}{l}\text { NR, } \\
7 \text { months }\end{array}$ & $\begin{array}{l}\text { high-dose } \\
\text { fluticasone } \\
(1,720 \mathrm{mg} / \text { day }) \\
\text { and salmeterol } \\
\text { (200 mg/day) }\end{array}$ & $\begin{array}{l}\text { CSS, diarrhoea, fatigue, shortness of } \\
\text { breath, rash, bibasilar rales, occult } \\
\text { blood, neuropathy, pulmonary } \\
\text { infiltrates, leucocytosis, eosinophilia }\end{array}$ & $\begin{array}{l}\text { partial resolution, } \\
\text { neuropathy }\end{array}$ \\
\hline & case 3 & asthma & 38 , female & $\begin{array}{l}\text { NR, } \\
2 \text { months }\end{array}$ & $\begin{array}{l}\text { inhaled steroids } \\
\text { and } \beta \text { agonist }\end{array}$ & $\begin{array}{l}\text { CSS, pulmonary infiltrates, leucocytosis, } \\
\text { eosinophilia }\end{array}$ & resolution \\
\hline & case 4 & asthma & 63 , female & $\begin{array}{l}\text { NR, } \\
6 \text { months }\end{array}$ & $\begin{array}{l}880 \mu \mathrm{g} \text { fluticasone } \\
\text { once daily }\end{array}$ & $\begin{array}{l}\text { CSS, leucocytosis, eosinophilia, muscle } \\
\text { pain, neuropathy }\end{array}$ & resolution \\
\hline
\end{tabular}

$\mathrm{NR}=$ Not reported; ANCA = antineutrophil cytoplasmic antibody; ANA = antinuclear antibody. 
Table 2. Summary of the case reports on montelukast-induced ADRs

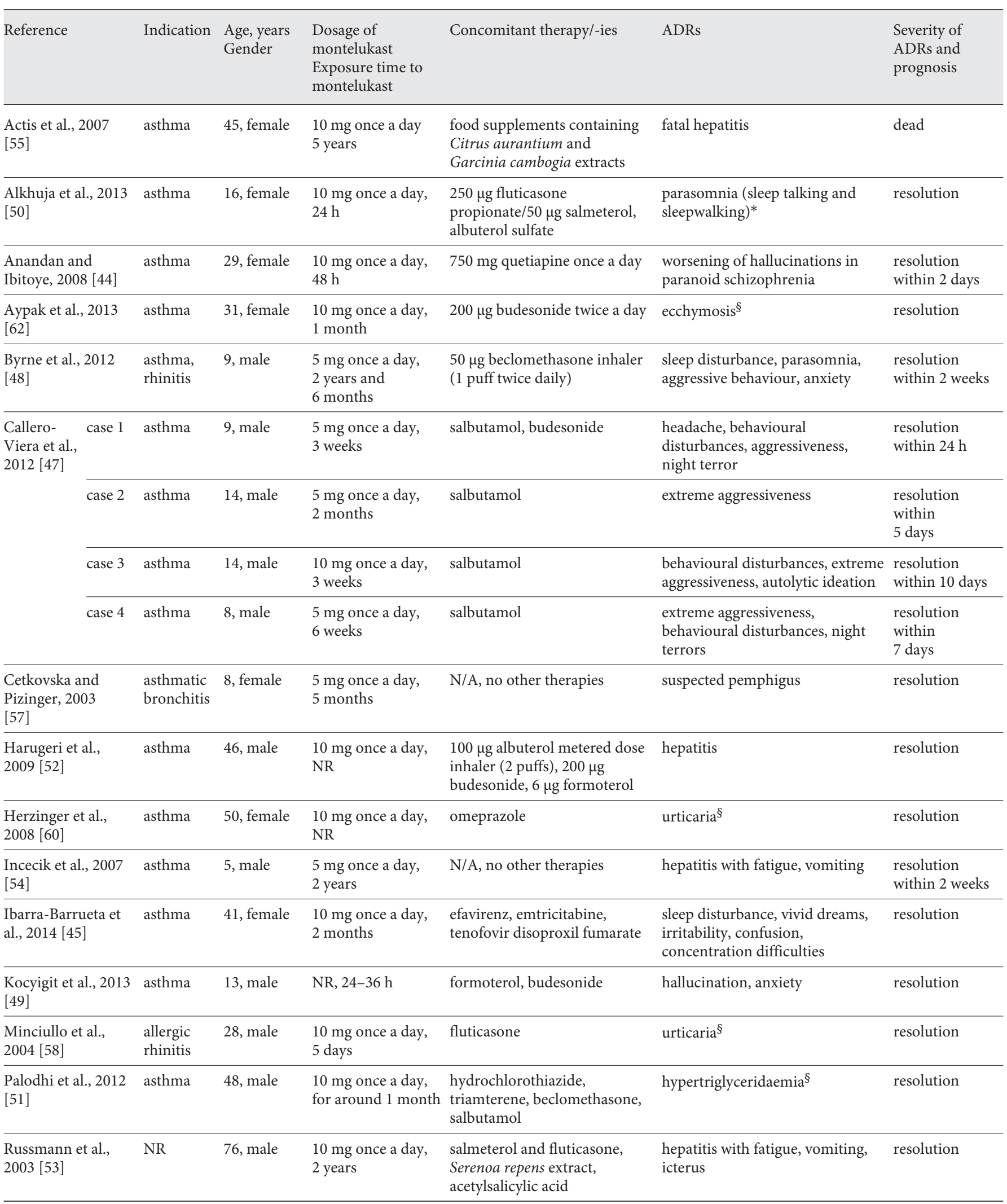


Table 2. (continued)

\begin{tabular}{|c|c|c|c|c|c|c|}
\hline Reference & Indication & $\begin{array}{l}\text { Age, years } \\
\text { Gender }\end{array}$ & $\begin{array}{l}\text { Dosage of } \\
\text { montelukast } \\
\text { Exposure time to } \\
\text { montelukast }\end{array}$ & Concomitant therapy/-ies & ADRs & $\begin{array}{l}\text { Severity of } \\
\text { ADRs and } \\
\text { prognosis }\end{array}$ \\
\hline $\begin{array}{l}\text { Sabbagh and } \\
\text { Sheikh-Taha, } 2009 \\
{[61]}\end{array}$ & allergy & 46 , female & $\begin{array}{l}10 \text { mg once a day, } \\
1 \text { month }\end{array}$ & $10 \mathrm{mg}$ ebastine & angio-oedema & resolution \\
\hline Tayeb, 2013 [63] & asthma & 30 , female & $\begin{array}{l}10 \text { mg, just } 1 \\
\text { administration }\end{array}$ & budesonide, formoterol & $\begin{array}{l}\text { urticaria, shortness of breath, } \\
\text { lip swelling }\end{array}$ & resolution \\
\hline Tedeschi, 2009 [59] & urticaria & 23 , male & $\begin{array}{l}10 \mathrm{mg} \text {, just } 1 \\
\text { administration }\end{array}$ & prednisone & urticaria & $\begin{array}{l}\text { resolution with } \\
\text { azathioprine }\end{array}$ \\
\hline
\end{tabular}

signs, including fever, malaise, arthralgias, clinical jaundice, peripheral blood eosinophilia, eosinophilic hepatitis, scleritis and arthritis [19-30]. Pulmonary involvement can be prominent, and chest radiography can show mixed alveolar-interstitial eosinophilic (80\%) infiltrates in the upper lobes [31]. Anar et al. [30] also reported haemoptysis. In some patients, LTRA-induced CSS can appear as skin lesions described as generalized bullous vasculitic rash or cutaneous necrotizing vasculitis [23, $26,32]$. In one case, a woman had a necrotic lesion in the foot suggestive of CSS [33]. Two case reports suggested that montelukast can act as a trigger for glomerulonephritis, a complication of CSS $[4,20]$. Some other articles reported CSS with a prevalent cardiac involvement, which is considered a bad prognostic indicator [34]; and in one case, it was reported in a patient developing progressive heart failure along with severe obstructive symptoms [35]. In other case reports, patients with CSS experienced peripheral neuropathy $[22,36]$, which can persist even after montelukast has been discontinued and a successive improvement of CSS $[21,22,32]$. The time elapsed between the administration of montelukast and the development of clinically evident CSS was really short in some cases, less than 7 days, while in other cases, a latency of 6 months or even years has been observed $[30,37]$.

According to these case reports, patients who developed LTRA-induced CSS were also receiving other therapies; corticosteroids were the most common among them in combination with beta stimulants. Many patients were on salmeterol or salbutamol plus fluticasone propionate [19, 21, 24, 26, 27, 32, 38, 39]. In some cases, the drugs taken by the patient included salbutamol, nedocromil, theophylline and beclomethasone [31]. In another case, described by Michael and Murphy [22], the patient took beclomethasone, ipratropium and salbutamol. In the case report by Mukhopadhyay and Stanley [38], the treatment consisted of budesonide, terbutaline and prednisolone $[36,38]$. One of the patients in Solans et al.'s [21] case series was also taking aspirin and nifedipine.

Many investigators performed biopsy assessments for a more accurate diagnosis. It was confirmed that CSS may involve open lungs $[24,30,34]$ and the skin $[23,38]$. Summarizing the case reports, the management of LTRA-induced CSS consisted of discontinuing the use of montelukast and the uptake of systemic corticosteroids, such as mometasone $[20,32,34,37]$ and methylprednisolone [19, $21,25,26,35]$. Some authors managed CSS adding the immunosuppressive drugs cyclophosphamide and azathioprine to the steroids [21, 26, 32], while Villena et al. [19] treated their patient with antibiotics and methylprednisolone.

In all these cases, montelukast was the suspect medication. All patients only showed symptoms after they had started the therapy, and the symptoms seemed to remit after the medication had been withdrawn. The concomitant decrease in oral corticosteroids, while taking montelukast, in some patients suggests the possible unmasking of an underlying autoimmune pathology. In other cases, the association between montelukast and CSS seems causal, because of the chronological consequentiality of the pathology development and the remission after withdrawing the medication. 


\section{Psychiatric and Nervous System Disorders}

Agitation Including Aggressive Behaviour or Hostility, Anxiousness, Depression, Disorientation, Dream Abnormalities, Hallucinations, Insomnia, Irritability, Restlessness, Somnambulism, Suicidal Thinking and Behaviour (Suicidality), Tremor, Dizziness, Drowsiness, Paraesthesia/Hypoesthesia, Very Rarely Seizures

In 2009, the FDA issued a warning regarding potential suicidality after taking montelukast and other leucotriene antagonists. However, according to a study conducted by Manalai et al. [40], there are not sufficient data to prove a link between montelukast and suicidality. A survey among 20,000 adults and children receiving this treatment showed no reports of completed suicide, and possible suicidality-related AEs were rare; furthermore, the events were similar to those seen in the control subjects [41]. Interestingly, Schumock et al. [42] conducted a regression analysis showing that the relationship between montelukast and suicidality could actually be in the opposite direction (i.e. there is a reduced risk). We found three reports in the literature about hallucinations after taking montelukast. Data collected in Sweden (in 1998$2007)$ indicated that having nightmares $(\mathrm{n}=15)$ and hallucinations were the most common montelukast-induced psychiatric ADRs $(n=48)$ [43]. Another case report described a 29-year-old asthmatic woman with auditory and visual hallucinations, which stopped within 2 days after montelukast withdrawal [44]. In an HIV-positive female patient, neuropsychiatric disturbances (i.e. disturbed sleep, vivid dreams, irritability, confusion and concentration difficulties) appeared when montelukast was added to efavirenz, and they disappeared completely after montelukast withdrawal [45]. These reported symptoms might have been caused by a drug-drug interaction between efavirenz and montelukast. This explanation was supported by the inhibitory effects of efavirenz on CYP 2C9, 2C19 and 3A4 activity and by the involvement of CYP 3A4, 2C9 and 2C8 in the metabolism of montelukast [45].

Sleep disturbances, including nightmares, have not been described in clinical trials on montelukast, while several cases have been reported in post-marketing surveillance. Cereza et al. [46] reviewed 24 cases who reported nightmares, both in adults $(\mathrm{n}=7)$ and in children $(\mathrm{n}=$ 17). Among them, 14 patients had other concomitant psychiatric symptoms, and in all these cases the suspect medication was montelukast. All these symptoms are, however, included in the SPC of montelukast [46]. Four children, aged between 1 and 5 years, developed sleep disorders (i.e. insomnia, somnolence and night terrors) as well as behavioural and mood disorders while receiving montelukast [47]. None of them had formerly reported psychiatric disorders. Three of the 4 children expressed suicidal ideation. After montelukast withdrawal, all these symptoms disappeared [47]. A 9-year-old boy on montelukast therapy for several years experienced neuropsychiatric events consisting of sleepwalking, sleep disturbance, bruxism and anxiety worsened by stressful events [48]. Kocyigit et al. [49] reported the case of a 13-year-old patient who had visual hallucinations after starting a therapy with montelukast, which disappeared within $48 \mathrm{~h}$ after the cessation of drug intake. Alkhuja et al. [50] observed the case of a 16-year-old female who received montelukast for asthma. In the nights following the therapy start, the patient's mother reported daily parasomnias in the form of sleep talking and sleepwalking. Montelukast was discontinued which resulted in a disappearance of the parasomnias. After re-challenge, the parasomnias appeared again. Once montelukast was definitely discontinued, the parasomnias were never reported again [50].

In these articles, both adults and children seem to develop psychiatric symptoms after the intake of the medication. In every patient, the symptomatology seems to become less with the discontinuation of the therapy with montelukast within few hours. Although anti-leucotrienes are safe drugs, these symptoms have to be monitored especially in children.

\section{Hepatobiliary Disorders and Pancreatic Disorders}

Increased ALT and AST Levels, Very Rarely

Hepatitis (Including Cholestatic, Hepatocellular

and Mixed-Pattern Liver Injury)

Palodhi et al. [51] observed the case of a male patient who developed hypertriglyceridemia and associated lipid profile abnormalities after taking montelukast. He had also been receiving salbutamol inhalation since childhood. Montelukast was withdrawn immediately, and his triglyceride values reached a level close to baseline after 4 months [51]. A 46-year-old male with uncontrolled asthma on inhaled albuterol and formoterol with budesonide was commenced on montelukast. Montelukast was discontinued due to suspected hepatocellular liver injury. His liver test results improved and returned to normal 55 days after drug cessation. A causality of this ADR was 'probable', based on the Council for International Organizations of Medical Sciences or Roussel Uclaf
Calapai/Casciaro/Miroddi/Calapai/ Navarra/Gangemi 
Causality Assessment Method (CIOMS or RUCAM) and Naranjo's algorithm [52]. Russmann et al. [53] observed an $\mathrm{AE}$ in a 76-year-old man characterized by fatigue, vomiting and icterus, with elevated aminotransferase, bilirubin and alkaline phosphatase levels. His therapy had consisted of salmeterol, fluticasone and Serenoa repens extract for 4 years and acetylsalicylic acid for 9 years. He had no alcohol history; and his viral, serological and autoantibody tests were negative. After suspending montelukast and Serenoa repens, his status improved and the laboratory values normalized. A liver biopsy and lymphocyte transformation test were performed: positive with montelukast [53]. Notably a 5 -year-old asthmatic patient suffered from fatigue, nausea, vomiting and abdominal pain due to hepatotoxicity caused by montelukast [54]. Actis et al. [55] described a 45-year-old woman who began complaining about nausea, vomiting and malaise after having received montelukast for 5 years. One week before this episode, she had received a 1-week treatment with two dietary supplements for weight control, and one of these contained Garcinia cambogia. She subsequently died, and her death was related to fatal hepatitis. A relationship and potential synergy between the food supplement and montelukast were suspected as the cause of hepatotoxicity [55]. A 22-year-old male patient experienced unusual weight gain and severe abdominal pain after 2 months of therapy with montelukast. The clinical and laboratory findings revealed the presence of an acute pancreatitis, hypercholesterolemia and severe hypertriglyceridemia. Clinical recovery followed montelukast discontinuation. Naranjo's algorithm suggested that the association could be considered as 'probable' [56].

Hypertriglyceridemia can be detrimental not only for individuals with a cardiovascular risk profile but also for healthy subjects, so blood values should be monitored in every patient on montelukast therapy.

\section{Skin and Subcutaneous Tissue Disorders}

Angio-Oedema, Bruising, Erythema Nodosum, Pruritus, Rash and Urticaria

There is a case report on an 8-year-old girl with a 2-month history of widespread erythematous and bullous eruptions, mostly affecting her lower extremities. The girl had a 2-year history of chronic asthmatic bronchitis. Montelukast had been initiated 5 months before the onset of the skin lesions; the authors suspected pemphigus [57].

Our group [58] reported on the case of a 28-year-old man with allergic rhinitis and moderate persistent asth- ma who developed generalized urticaria 5 days after starting on montelukast and inhaled fluticasone. His symptoms disappeared 1 day after the suspension of both drugs. Two months later, after the resumption of montelukast and fluticasone, the patient developed urticaria again with eyelid angio-oedemas, which were successfully treated with intravenous betamethasone, achieving complete remission. The patient resumed only inhaled fluticasone without any further adverse reactions [58]. Tedeschi [59] reported the case of a patient with no IgEmediated chronic urticaria, exacerbated by various medications including montelukast. Cyclosporine and azathioprine controlled the patient's symptoms [59]. Another case of montelukast-induced urticaria, in a 50 -year-old woman, was described by Herzinger et al. [60]. A 46-yearold woman with a history of severe allergies and angiooedemas had an acute angio-oedema episode. The patient was on ebastine $10 \mathrm{mg}$ daily, montelukast $10 \mathrm{mg}$ daily and vitamins and reported that since she had started montelukast 1 month prior, she had experienced three similar episodes, the first occurring 5 days after starting the drug [61]. There is a case report on a 31-year-old woman with a history of allergic rhinitis and asthma, who experienced severe bruising on her lower extremities after starting montelukast. De-challenge and subsequent re-challenge of montelukast confirmed the connection between the drug and lesions. The authors excluded a traumatic origin, concomitant CSS and food allergy, and the skin biopsy revealed unspecific inflammatory signs [62]. Tayeb [63] reported the case of a young woman who developed the following recurrent symptoms after taking montelukast: lip swelling, maculopapular skin rash and shortness of breath. The author performed a desensitization procedure to the anti-leucotriene [63].

Dermatitis and urticaria are frequent adverse reactions against drugs and they have been reported with montelukast, too.

\section{Uropoietic System}

\section{Haematuria}

Xie et al. [64] observed montelukast-induced haematuria in a 58-year-old female patient. Her gross haematuria improved 7 days after montelukast withdrawal. Two weeks later, her renal function returned to normal [64].

Haematuria and glomerulonephritis can be considered one aspect of an unexpected immune response triggered by the intake of montelukast and resulting in a subclinical CSS. 


\section{Discussion}

Montelukast is, in general, a well-tolerated drug, both in adult and paediatric patients. Safety data provided by clinical trials highlight no substantial difference in AEs to placebo. The most common AEs observed in these trials were: headache, gastrointestinal disorders, fatigue, pharyngitis, upper respiratory tract infection and rash [6567]. However, clinical trials are often conducted in highly selective patient subgroups, this must be taken into account when drawing conclusions from the SPC of montelukast.

Several case reports describe montelukast-induced CSS. This rare vasculitis presents a broad range of clinical manifestations, sometimes characterized by a severe prognosis and permanent sequelae. CSS affects especially adult patients of both genders. Unfortunately, to date, the mechanisms underlying the onset of CSS are not fully understood.

In the analyzed case reports, CSS repeatedly appears to occur when usual corticosteroid therapy is gradually tapered or discontinued [22]. Some authors advanced the hypothesis of a decreasing corticosteroid dose unmasking an underlying CSS $[28,39]$. We suggest that more appropriate epidemiological studies on the role of montelukast in the pathogenesis of CSS are needed. Neuropsychiatric disorders and sleep disturbances, which affect the paediatric population more often, exert a negative impact on patients' quality of life, although most of them had a clinical resolution after montelukast discontinuation. Currently, the pharmacological mechanisms causing neuropsychiatric alterations are not clear.

Evidence of the presence of CysLT1 in the brain suggests that the pathway of CysLT receptors is more complex than it was initially supposed. Various pre-clinical experiments, exploring the function of this pathway in the central nervous system, reveal an over-expression in the reparative process occurring during particular pathological conditions [68]. Even though studies on children are lacking, it could be hypothesized that, in susceptible paediatric patients, blocking CysLT1 by its specific antagonists can cause neuropsychiatric adverse reactions.

Montelukast can cause hepatobiliary and pancreatic dysfunction. Notably, it has been described in a case of fatal hepatotoxicity; however, in this case it was not possible to describe the mechanism triggering hepatotoxicity. Interestingly, various experimental models of druginduced hepatotoxicity in rats showed a protective effect of montelukast [69].

\section{Conclusion}

In the light of the present review, it appears clear that montelukast administration can be burdened by several ADRs, of which physicians should be aware in their clinical practice, taking into account that the administration of montelukast, along with concomitant therapies, could increase the risk of drug-drug interaction. A better comprehension of the mechanisms causing ADRs related to this anti-leucotriene could help researchers and clinicians to define a therapeutic strategy aimed to reduce montelukast toxicity. Furthermore, it is desirable to conduct more accurate epidemiological studies on large populations in order to definitively discover risk factors favouring montelukast-associated ADRs.

\section{Disclosure Statement}

The authors of the present article declare that they have no conflicts of interest.

\section{References}

1 Peters-Golden M, Gleason MM, Togias A: Cysteinyl leukotrienes: multi-functional mediators in allergic rhinitis. Clin Exp Allergy 2006;36:689-703.

2 Fal AM, Kopec A: Status of leukotrienes in the pathophysiology of asthma. Necessity for antileukotrienes treatment (in Polish). Pneumonol Alergol Pol 2010;78:68-73.

-3 Shirasaki H, Kanaizumi E, Seki N, Fujita M, Kikuchi M, Himi T: Localization and up-regulation of cysteinyl leukotriene-2 receptor in human allergic nasal mucosa. Allergol Int 2013;62:223-228.
4 Kanda T, Tanio H, Wu C, Nishihara H, Nogaki F, Ono T: Churg-Strauss syndrome with severe granulomatous angiitis and crescentic glomerulonephritis, which developed during therapy with a leukotriene receptor antagonist. Clin Exp Nephrol 2010;14:602-607.

5 Sircar G, Saha B, Bhattacharya SG, Saha S: Allergic asthma biomarkers using systems approaches. Front Genet 2014;4:308.

-6 Masoli M, Fabian D, Holt S, Beasley R: The global burden of asthma: executive summary of the GINA Dissemination Committee report. Allergy 2004;59:469-478.
7 Joos S, Miksch A, Szecsenyi J, Wieseler B, Grouven U, Kaiser T, Schneider A: Montelukast as add-on therapy to inhaled corticosteroids in the treatment of mild to moderate asthma: a systematic review. Thorax 2008;63: 453-462.

8 Haselkorn T, Chen H, Miller DP, Fish JE, Peters SP, Weiss ST, Jones CA: Asthma control and activity limitations: insights from the Real-world Evaluation of Asthma Control and Treatment (REACT) study. Ann Allergy Asthma Immunol 2010;104:471477.
68

Pharmacology 2014;94:60-70 DOI: $10.1159 / 000366164$
Calapai/Casciaro/Miroddi/Calapai/

Navarra/Gangemi 
9 Bozek A, Jarzab J: Adherence to asthma therapy in elderly patients. J Asthma 2010;47: 162-165.

10 Keith PK, Koch C, Djandji M, Bouchard J, Psaradellis E, Sampalis JS, Schellenberg RR, McIvor RA: Montelukast as add-on therapy with inhaled corticosteroids alone or inhaled corticosteroids and long-acting beta-2-agonists in the management of patients diagnosed with asthma and concurrent allergic rhinitis (the RADAR trial). Can Respir J 2009; 16(suppl A):17A-31A.

11 Bisgaard H, Skoner D, Boza ML, Tozzi CA, Newcomb K, Reiss TF, Knorr B, Noonan G: Safety and tolerability of montelukast in placebo-controlled pediatric studies and their open-label extensions. Pediatr Pulmonol 2009;44:568-579.

$\checkmark 12$ Kroegel C: Global Initiative for Asthma (GINA) guidelines: 15 years of application. Expert Rev Clin Immunol 2009;5:239-249.

13 Chauhan BF, Ben Salah R, Ducharme FM: Addition of anti-leukotriene agents to inhaled corticosteroids in children with persistent asthma. Cochrane Database Syst Rev 2013; 10:CD009585.

14 Chauhan BF, Ducharme FM: Anti-leukotriene agents compared to inhaled corticosteroids in the management of recurrent and/ or chronic asthma in adults and children. Cochrane Database Syst Rev 2012; 5: CD002314.

15 Pagnoux C: Churg-Strauss syndrome: evolving concepts. Discov Med 2010;9:243-252.

-16 Camargo CA Jr, Gurner DM, Smithline HA, Chapela R, Fabbri LM, Green SA, Malice MP, Legrand C, Dass SB, Knorr BA, Reiss TF: A randomized placebo-controlled study of intravenous montelukast for the treatment of acute asthma. J Allergy Clin Immunol 2010; 125:374-380.

17 Guillevin L, Cohen P, Gayraud M, Lhote F, Jarrousse B, Casassus P: Churg-Strauss syndrome. Clinical study and long-term followup of 96 patients. Medicine (Baltimore) 1999; 78:26-37.

18 Bibby S, Healy B, Steele R, Kumareswaran K, Nelson H, Beasley R: Association between leukotriene receptor antagonist therapy and Churg-Strauss syndrome: an analysis of the FDA AERS database. Thorax 2010;65:132138.

19 Villena V, Hidalgo R, Sotelo MT, Martin-Escribano P: Montelukast and Churg-Strauss syndrome. Eur Respir J 2000;15:626.

20 Goransson LG, Omdal R: A severe systemic inflammatory reaction following therapy with montelukast (Singulair). Nephrol Dial Transplant 2000;15:1054-1055.

21 Solans R, Bosch J, Selva A, Orriols R, Vilardell M: Montelukast and Churg-Strauss syndrome. Thorax 2002;57:183-185.

22 Michael AB, Murphy D: Montelukast-associated Churg-Strauss syndrome. Age Ageing 2003;32:551-552.

23 Cuchacovich R, Justiniano M, Espinoza LR: Churg-Strauss syndrome associated with leu- kotriene receptor antagonists (LTRA). Clin Rheumatol 2007;26:1769-1771.

24 Currie GP, McKinlay L, Kerr KM: Histological appearances of putative montelukast related Churg-Strauss syndrome. Thorax 2008; 63:1120.

25 Girszyn N, Amiot N, Lahaxe L, Cuvelier A, Courville P, Marie I: Churg-Strauss syndrome associated with montelukast therapy. QJM 2008;101:669-671.

26 Jennings L, Ho WL, Gulmann C, Murphy GM: Churg-Strauss syndrome secondary to antileucotriene therapy in a patient not receiving oral corticosteroids. Clin Exp Dermatol 2009;34:e430-e431.

27 Man MA, Alexandrescu D, Pop M, Trofor A: Churg Strauss syndrome associated with montelukast - case report. Pneumologia 2012;61:113-116

28 Wechsler ME, Finn D, Gunawardena D, Westlake R, Barker A, Haranath SP, Pauwels RA, Kips JC, Drazen JM: Churg-Strauss syndrome in patients receiving montelukast as treatment for asthma. Chest Journal 2000; 117:708-713.

29 Matsui K, Nishijima K: A case of montelukast-induced Churg-Strauss syndrome associated with liver dysfunction. Case Reports in Hepatology 2011, DOI: dx.doi.org/10.1155/ 2011/412524.

-30 Anar C, Unsal I, Ozanturk ME, Halilcolar H, Yucel N: A case of Churg-Strauss syndrome treated with montelukast. Med Princ Pract 2012;21:186-189.

31 Franco J, Artés MJ: Pulmonary eosinophilia associated with montelukast. Thorax 1999;54: 558-560.

32 Tuggey JM, Hosker HS: Churg-Strauss syndrome associated with montelukast therapy. Thorax 2000;55:805-806.

-33 Carlesimo M, Mari E, Palese E, Pranteda G, Camplone G: Churg-Strauss and montelukast. Int J Immunopathol Pharmacol 2011;24: 1079-1082.

34 Black JG, Bonner JR, Boulware D, Andea AA: Montelukast-associated Churg-Strauss vasculitis: another associated report. Ann Allergy Asthma Immunol 2009;102:351352.

35 Conen D, Leuppi J, Bubendorf L, Ronsdorf A, Tamm M, Hauser T: Montelukast and ChurgStrauss syndrome. Swiss Med Wkly 2004;134: 377-380.

36 Zandman-Goddard G, Sylantiev C, Langevitz P: Montelukast-related Churg-Strauss vasculitis presenting with peripheral neuropathy. Isr Med Assoc J 2007;9:50-51.

37 Guilpain P, Viallard JF, Lagarde P, Cohen P, Kambouchner M, Pellegrin JL, Guillevin L: Churg-Strauss syndrome in two patients receiving montelukast. Rheumatology 2002;41: 535-539.

38 Mukhopadhyay A, Stanley NN: ChurgStrauss syndrome associated with montelukast. Postgrad Med J 2001;77:390-391.

39 Uyar M, Elbek O, Bakir K, Kibar Y, Bayram N, Dikensoy O: Churg-Strauss syndrome re- lated to montelukast. Tuberk Toraks 2012;60: 56-58.

40 Manalai P, Woo JM, Postolache TT: Suicidality and montelukast. Expert Opin Drug Saf 2009;8:273-282.

41 Philip G, Hustad C, Noonan G, Malice MP, Ezekowitz A, Reiss TF, Knorr B: Reports of suicidality in clinical trials of montelukast. J Allergy Clin Immunol 2009;124:691-696.e6.

42 Schumock GT, Stayner LT, Valuck RJ, Joo MJ, Gibbons RD, Lee TA: Risk of suicide attempt in asthmatic children and young adults prescribed leukotriene-modifying agents: a nested case-control study. J Allergy Clin Immunol 2012;130:368-375.

43 Wallerstedt SM, Brunlof G, Sundstrom A, Eriksson AL: Montelukast and psychiatric disorders in children. Pharmacoepidemiol Drug Saf 2009;18:858-864.

44 Anandan N, Ibitoye F: Montelukast and worsening of hallucinations in paranoid schizophrenia. Psychiatric Bulletin 2008;32: 276-276.

45 Ibarra-Barrueta O, Palacios-Zabalza I, MoraAtorrasagasti O, Mayo-Suarez J: Effect of concomitant use of montelukast and efavirenz on neuropsychiatric adverse events. Ann Pharmacother 2014;48:145-148.

46 Cereza G, Garcia Dolade N, Laporte JR: Nightmares induced by montelukast in children and adults. Eur Respir J 2012;40:15741575.

47 Callero-Viera A, Infante S, Fuentes-Aparicio V, Zapatero L, Alonso-Lebrero E: Neuropsychiatric reactions to montelukast. J Investig Allergol Clin Immunol 2012;22:452-453.

48 Byrne F, Oluwole B, Whyte V, Fahy S, McGuinness D: Delayed onset of neuropsychiatric effects associated with montelukast. Ir J Psych Med 2012;29:125-127.

49 Kocyigit A, Gulcan Oksuz B, Yarar F, Uzun F, Igde $\mathrm{M}$, Islek I: Hallucination development with montelukast in a child with asthma: case presentation. Iran J Allergy Asthma Immunol 2013;12:397-399.

50 Alkhuja S, Gazizov N, Alexander ME: Sleeptalking! Sleepwalking! Side effects of montelukast. Case Rep Pulmonol 2013;2013:813786.

51 Palodhi S, Ray Chaudhuri P, Biswas A, Bera T: Montelukast induced hypertriglyceridemia. Indian Med Gaz 2012;146:334-336.

-52 Harugeri A, Parthasarathi G, Sharma J, D’Souza GA, Ramesh M: Montelukast induced acute hepatocellular liver injury. J Postgrad Med 2009;55:141-142.

53 Russmann S, Iselin HU, Meier D, Zimmermann A, Simon HU, Caduff P, Reichen J: Acute hepatitis associated with montelukast. J Hepatol 2003;38:694-695.

54 Incecik F, Onlen Y, Sangun O, Akoglu S: Probable montelukast-induced hepatotoxicity in a pediatric patient: case report. Ann Saudi Med 2007;27:462-463.

55 Actis GC, Bugianesi E, Ottobrelli A, Rizzetto M: Fatal liver failure following food supplements during chronic treatment with montelukast. Dig Liver Dis 2007;39:953-955. 
56 Das S, Mondal S, Dey JK, Bandyopadhyay S, Saha I, Tripathi SK: A case of montelukast induced hypercholesterolemia, severe hypertriglyceridemia and pancreatitis. J Young Pharm 2013;5:64-66.

57 Cetkovska P, Pizinger K: Childhood pemphigus associated with montelukast administration. Clin Exp Dermatol 2003;28:328-329.

58 Minciullo PL, Saija A, Bonanno D, Ferlazzo E, Gangemi S: Montelukast-induced generalized urticaria. Ann Pharmacother 2004;38: 999-1001.

-59 Tedeschi A: Paradoxical exacerbation of chronic urticaria by $\mathrm{H} 1$-antihistamines and montelukast. Eur Ann Allergy Clin Immunol 2009;41:187-189.

60 Herzinger T, Ludolph-Hauser D, Przybilla B: Urticaria triggered by antiallergy treatment. Clin Exp Dermatol 2008;33:519-520.
61 Sabbagh R, Sheikh-Taha M: Possible montelukast-induced angioedema. Am J Health Syst Pharm 2009;66:1705-1706.

62 Aypak C, Turedi O, Solmaz N, Yikilkan H, Gorpelioglu S: A rare adverse effect of montelukast treatment: ecchymosis. Respir Care 2013;58:e104-e106.

63 Tayeb MMS: Allergy to montelukast sodium treated effectively by protracted oral desensitization: first case report. J Aller Ther 2013; $4: 2$

64 Xie JX, Wei JF, Meng L: Montelukast sodiuminduced hematuria: a case report and literature review of 19 cases in mainland China. Int J Clin Pharmacol Ther 2013;51:958-962.

65 Ducharme FM, Lasserson TJ, Cates CJ: Addition to inhaled corticosteroids of long-acting beta2-agonists versus anti-leukotrienes for chronic asthma. Cochrane Database Syst Rev 2011:CD003137.
66 Scichilone N, Battaglia S, Benfante A, Bellia V: Safety and efficacy of montelukast as adjunctive therapy for treatment of asthma in elderly patients. Clin Interv Aging 2013;8:13291337.

67 Singh RK, Tandon R, Dastidar SG, Ray A: A review on leukotrienes and their receptors with reference to asthma. J Asthma 2013;50: 922-931.

68 Ding Q, Fang SH, Zhou Y, Zhang LH, Zhang WP, Chen Z, Wei EQ: Cysteinyl leukotriene receptor 1 partially mediates brain cryoinjury in mice. Acta Pharmacol Sin 2007;28:945952

-69 Cuciureanu M, Căruntu ID, Păduraru O, Stoica B, Jerca L, Crauciuc E, Nechifor M: The protective effect of montelukast sodium on carbon tetrachloride induced hepatopathy in rat. Prostaglandins Other Lipid Mediat 2009; $88: 82-88$ 